the University of Aberdeen. This appointment will be received with a great deal of interest by all in the biochemical field, and with an element of surprise perhaps by some, for the appointment is probably unique in scientific circles in that Dr. Kermack is blind. To proceed to such an appointment in a laboratory subject has something in it of an act of faith, based not alone on the high scientific attainments but also on the rich mental endowments and sterling qualities of the new professor.

Dr. Kermack is an honours graduate in chemistry of the University of Aberdeen, where he received his B.Sc. degree in 1918. It was while a postgraduate research worker at Edinburgh that, in the course of an experiment, he met with the tragic accident which deprived him of all vision. To a lesser spirit such a catastrophe might well have spelt defeat; to Kermack it was but a challenge to re-orient his life to the steady continuance of his scientific work. That success has attended his efforts to a remarkable degree is seen in his activities in the spheres of mathematics, chemistry and music. His early research work was carried out in Oxford under the supervision first of Prof. W. H. Perkin and latterly of Sir Robert Robinson; his later work in colloid chemistry, on certain reactions of serum and cerebrospinal fluid, led on to the synthesis of compounds of possible antimalarial activity. This work has resulted in the synthesis of pyridoacridine and of $p$-phenanthroline derivatives, which have considerable chemotherapeutic activity on avian malaria. Dr. Kermack is joint author with Dr. P. Eggleton of "The Stuff We're Made Of" (1938); he is a D.Sc. of Aberdeen, was awarded the Freeland-Barbour Prize of the Royal College of Physicians, Edinburgh, the Macdougall-Brisbane Prize of the Royal Society of Edinburgh (1929), received the honorary degree of LL.D. of the University of St. Andrews in 1937 and was elected a fellow of the Royal Society in 1944.

\section{Genetics at the John Innes Horticultural Institu- tion Dr. D. Lewis}

Dr. D. LewIs is succeeding Dr. Mather, recently appointed to the chair of genetics at Birmingham, as head of the Genetics Department at the John Innes Horticultural Institution. Dr. Lewis was appointed from Reading in 1935 to work in the Pomology Department at the Institution. He has collaborated with Mr. M. B. Crane in the breeding of pears, raspberries and other fruits. For the last ten years, however, he has concentrated on the study of the incompatibility reaction in plants, using especially the Californian Oenothera organensis. He began with simple tests on the temperature relations. Later he introduced polyploidy and mutations, both spontaneous and induced, into his experiments. He has been able to split the incompatibility gene in Oenothera, with results of great physiological interest. He has also been able to calculate its natural mutation-rate in the sweet cherry, and at the same time use the mutations in producing self-fertile types in a hitherto self-incompatible species-a breeding device of great practical interest. Dr. Lewis' versatile experimental gifts should find suitable scope in his new post.

\section{Women as a Labour Force in Britain}

IN Broadsheet No. 285, "Employment of Women", Planning (P.E.P.) examines some of the implications of the task of maintaining, and if possible increasing, the female labour of Britain at a time when the num- ber of women of working age is declining. The difficulty is enhanced by the even greater decline in the number of women under forty-five years of age, from whom the bulk of the female labour force is drawn. The broadsheet points out that it is very important that employers should not be unprepared for the probable fall in the number of women in employment during the next fifteen years. The Ministry of Labour should forecast the probable trend in the number of women available for work in the various industries and regions, and should make the findings widely known. It must then be considered whether rising productivity will make good the loss of women workers, and if not, what adjustments should be made ; in particular, whether to try to maintain the proportion of women in certain industries and occupations, or whether to allow the proportion to fall in all. Two conclusions stand out : first, that any substantial increase in the number of women in employment must come from married women; and, secondly, that if the female labour force is not to fall greatly, there must be a big rise in the number of middle-aged and elderly women in employment. By far the most hopeful means is to extend the opportunities for part-time workers. This is a desirable solution from the women's point of view ; but from the employers' aspect entails careful organisation, additional supervision, and flexibility. In compensation there is evidence that part-time workers give good service, that their output is often higher than that of full-time workers, and that absenteeism and labour turn-over do not compare unfavourably. The importance of improving working conditions and providing more nurseries is stressed, and also of employing women who are in jobs to the best advantage. Those who aspire to a skilled, professional or executive job should have the opportunity, and the size, composition and distribution of the female labour force must not be left to chance.

\section{French Abstracts}

The Bulletin Analytique, published by the Centre National de la Recherche Scientifique, Paris, is an abstracting journal which appears monthly in two parts, Part 1 covering scientific and technical papers in the mathematical and physical sciences and their applications, Part 2 the biological sciences. The Bulletin, which started on a modest scale in 1940 with an average of 10,000 abstracts per part, now averages 35,000-40,000 abstracts per part. The abstracts summarize briefly papers in scientific and technical periodicals received in Paris from all over the world and cover the majority of the more important journals in the world scientific press. The scope of the Bulletin is constantly being enlarged to include a wider selection of periodicals. It thus provides a valuable reference book both for the laboratory and for the individual research worker who wishes to keep in touch with advances in subjects bordering on his own. A microfilm is made of each article as it is abstracted, and negative microfilm copies or prints from microfilm can be purchased from the editors. The subscription rates of the Bulletin Analytique for Great Britain are 4,000 fr. (£5) per annum for each part. The Bulletin is also issued in sections covering specific subjects. Subscriptions can be paid directly to the editors : Centre National de la Recherche Scientifique, 18 rue Pierre-Curie, Paris 5ème. (Compte-cheque-postal 2500-42, Paris), or through Messrs. H. K. Lewis and Co., Ltd., 136 Gower Street, London, W.C.1. 